\title{
Sustainable Disaster Risk Reduction in Nigeria: Lessons for Developing Countries
}

\author{
Olorunfemi, F.B \& Raheem U. Adebimpe
}

\begin{abstract}
:
This paper examined the concept of disaster and its management in the light of sustainable development with particular reference to Nigeria. It enumerated the different human and natural phenomena that could be characterized as disasters. It was discovered that, while hazard and/ or disasters posses anthropogenic origins, their consequences are felt on both human and the physical environments. In all cases, the human tolls have been significant. The paper highlighted the important elements of a typical Disaster Management Information System in Nigeria. After presenting a typology of disasters in Nigeria, the paper, advocated for a workable disaster management information system.
\end{abstract}

Keywords: Disaster Management, Risk, Hazards, Vulnerability,

\section{Introduction}

Disaster refers to an emergency caused by natural hazards or humaninduced actions resulting in a significant change in circumstances over a relatively short time period. Typical examples are death, displacement, disease, loss of crops, damage to physical and service infrastructure, depletion of natural and social capitals, institutional weakening and a general disruption of economic and social activity. A broad definition of disasters include the fact that they are dramatic, sudden, unscheduled events that are often accompanied by large losses of human life, suffering and affliction to a society or a significant part of it, and a temporary breakdown of prevailing lifelines and systems. Such events cause considerable material damages and interrupt the normal functioning of an economy and of society in general (Otero and Marti, 1995). The intensity of disasters 
often represent the intersection of human and natural disaster, conditions of poverty, poor housing, lack of information about disaster risk, poor telecommunications, and inadequate physical infrastructures, including bridges or roads, frequently exacerbate natural disasters such as floods, earthquakes, hurricanes, and volcanic eruption. Evacuations of large populations are complicated by lowcapacity infrastructure or family or cultural impediments. Although every nation is generally aware of their propensity for various kinds of human and natural disaster scenarios, their occurrence and consequences are often sudden, random and not well predicted.

Although, differing somewhat in the trigger, scope, duration and requisite actions, most disasters - both natural and human-driven generally result in widespread physical damage, death, disability and displacement, as well as the disruption of economic and social activities (Coletta, 2004, Olokesusi, 2004). Disaster specialists focus on two kinds of vulnerability. The first is peoples' vulnerability to disasters - the extent to which they are at risk (living on a flood plain, having a house unable to withstand floods) and the extent to which they can cope with the impacts (through such provisions as health care and property insurance). The second is the vulnerability of key institutions or systems such as power supplies, water supplies, and hospitals and emergency response networks to disasters.

During the past four decades, hazards events such as earthquakes, drought, floods, storms, fires and volcanic eruptions have caused major loss of human life and livelihoods; destruction of economic and social infrastructure and significant environmental damage. Moves towards sustainable development and poverty reduction initiatives are threatened by disasters triggered by hazards of hydro-meteorological, geological and environmental origins often amplified by human activities or technology (Ojo, 2003). According to Gavidia (2000), natural disasters such as earthquakes, floods and hurricanes can wipe out years of urban development by destroying infrastructure and housing and by injury or killing thousands of people. The $26^{\text {th }}$ 
December, 2004, tsunami disaster in South Asia is an example which led to an immense loss of over 270,000 lives in addition to several million dollars worth of property and infrastructure destroyed. Disasters and those prone to it increase human vulnerability. In the last millennium, and even now, the world has witnessed a range of natural hazards (environmental emergencies), in greater and more frequent in some areas than in others, slow-acting in some cases and catastrophic in others. The Munich Re-insurance estimated that economic losses due to environmental emergencies have increased three-fold from the 1960s to the 1990s, and in the first few years of this decade, are running about US $\$ 50$ billion per year. The majority of these enormous economic losses are incurred in industrially developed parts of the world including Japan, USA and Canada. But the relative impact is much greater in countries with lower per capital incomes, where their effects on such human and economic factors as employment, balance of trade, indebtedness from reconstruction and loss of capital continued to be felt for many years after the event (CERD, 2000; Mac Entire, 2001).

Developing nations in particular, experience pervasive risk of devastation, human and property loss resulting from human and natural disasters. According to Henderson (2004), this level of risk was attributable to socio-economic stress, aging and inadequate physical infrastructure, weak education and preparedness for disaster and insufficient fiscal and economic resources to carefully implement the preparedness, response, mitigation and recovery components of integrated emergency management. Disasters are clearly a development problem. First, because certain natural phenomena, including those of hydro-meteorological, geodesic and vulcanological origin tend to have greater effects on developing countries than on developed countries. Second, because several factors associated with a low level of development exacerbate such effects. Third, because the impact of natural phenomena on the prospects for long term development is considerably greater in less developed countries (BID, CEPAL, 2000). 
The growing trend of disasters in Nigeria has implications for national sustainability. This is because, disasters, irrespective of causal factors are associated with diverse externalities such as mortalities, loss of income, home, farmlands, social networks, livelihoods and infrastructures. The accelerating pace of urbanization and the growing scale of urban-industrial activity is exacerbating environmental stresses in developing-country cities and increasing the vulnerability of urban dwellers to both natural, technological and other human induced disasters (Kreimer and Munasingle, 1991). The demand for more urban space has pushed the poor onto marginal, environmentally vulnerable terrain. In many developing countries, overcrowding, congestion, poverty, unemployment, and in adequate infrastructure and services further weaken urban resistance to natural hazards (Clarke and Munasinghe, 1995).

All things considered, the long-term effects of disasters seriously affect countries' prospects for development. This calls into question at least two aspects related to a country's development strategy: first, understanding that resources earmarked for preventing and mitigating the impact of natural phenomena are very high-yield investment, both in economic, social and political terms in line with long-term growth. Second, the spending actions and decisions that are taken once a phenomenon has arisen must be seen from the perspective of reducing vulnerability, in other words, in a combined reconstruction and transformation approach aimed at positively and progressively modifying the degree of vulnerability and, therefore, the prospects for future development. This paper examined the critical factors in disaster risk management and vulnerability in Nigeria. It underscores the weaknesses of the social and political institutions and infrastructure to adequately prepare and respond to hazards and disasters.

\section{Disaster Management: Some Conceptual Clarifications}

Disaster management aims at motivating societies at risk to be more involved in the conscious management of risk and reduction of 
vulnerability in various communities. As a cross cutting issue, it demands substantial commitment from public authorities/ Civil society and a greater inter-sectoral and policy coordination at all levels. This section provides a clarification of some terms used in disaster management.

\section{Hazard}

A hazard can be defined as a potentially damaging physical event, phenomenon or human activity which may cause the loss or life or injury, property damage, social and economic disruption or environmental degradation. Hazards can include hidden conditions that may represent future threats and can have different origins. These include natural (geological, hydro-meteorological and biological) and/or induced by human processes (environmental degradation and technological hazards) (ISDR 2002: 24). According to Niekerk (2002), hazards can be single, sequential or combined in their origin and effects. Each hazard is characterized by its location, intensity and probability. Typical examples of hazards can be the absence of rain (leading to drought) or the abundance thereof (leading to flooding). Chemical manufacturing plants near settlements can also be seen as hazards. Similarly, incorrect agricultural techniques will in the long run lead to possible disasters such as loss of crops and famine. Hazards can either be a creation of humans or the environment. Although the farmer can be planned for than the latter, in both cases, the management of hazard will remain the same.

\section{Vulnerabilities}

Vulnerabilities is a set of prevailing or consequential conditions resulting from physical, social, economic and environmental factors, which increase the sustainability of a community to the impact of hazards (ISDR 2002: 24). It can comprise of physical, socioeconomic, environmental and/or political factors that adversely affect the ability of communities to respond to events (Jegillos, 1999). Blaike et al (1994) is of the opinion that vulnerability is the characteristics of person or group in terms of their capacity to 
anticipate, cope with, resist and recover from the impact of a hazard. Vulnerability can be expressed as the degree of loss resulting from potentially damaging phenomenon or hazard (Niekerk, 2002a). In other words, vulnerabilities can be measured by the level of fatality i.e. amount of deaths, losses of properties or cash etc. Population increases due to high birth rate and the lack of food governance do make communities in developing nations to be highly vulnerable to hazards. The community and its members may or may not be willing participants in contributing to or tolerating the conditions leading to vulnerability. Taken together, they create a dynamic mix of variables, each of which results from a continuous process. Vulnerabilities can be physical, social or attitudinal and can be primary or secondary in nature. If there are positive factors, that increase ability to respond to needs effectively or which reduce susceptibility, they are considered capabilities or coping mechanics.

\section{Aspects Contributing to Vulnerability:}

- Political factors

- Economic factors

- Physical factors

- Social factors

- Ecological factors

It has been established that vast knowledge on vulnerability and conditions that lead to vulnerability do exist.

\section{Risk}

Risk is usually associated with the inability of men to manage hazard events that may eventually lead to negative consequences like destruction of the environment, socio-economic activities, properties and losses of lives. Risk in terms of disaster management has a specific focus (UN, 1992). It can be defined as the probability of harmful consequences (ISDR, 2002), or expected losses (lives lost, persons injured, damage to property and/or the environment, livelihoods lost, disruption of economic activity or social systems) due to the interaction between humans, hazards and vulnerable conditions. 
Risk is therefore the possibility that a particular hazard might exploit a particular vulnerability (Nierkerk, 2002). It is the production of the possible damage caused by a hazard due to the vulnerability within a community. In other words, risk is usually due to hazard events exploiting the vulnerable situation of an environment or community. The poorer communities are more at risk because of their high vulnerability to hazard situations due to their low coping capacities. The perception of risk and causes vary from community to communities and culture to cultures. According to Moor (2001) cities as the most complex of human creations are more at great risk from their own multiple vulnerabilities. Points of urban vulnerabilities include their infrastructure systems, factories, telecommunications, transport, energy, food supplies, schools, offices etc. Two elements are essential in the formulation or risk: the probability of occurrence of a given threat (e.g. a hazard); and the degree of susceptibility of the element (e.g. a rural community) exposed to that source (vulnerability (ISDR, 2002: 41).

\section{Disasters}

A disaster is a serious disruption of the functioning of a society, causing or threatens to cause, widespread human, material, or environmental losses which exceed the ability of affected community to cope using only its own resources (South Africa, 2002). Disasters can be sudden (flash floods) or progressive (drought). Disasters are caused due to the interaction of humans with their environment. A disaster is a function of the risk process. It results from the combination of hazards, conditions of vulnerability and insufficient capacity or measures to reduce the potential negative consequences of risk (ISDR, 2002: 25). Extreme natural phenomena do not in themselves constitute hazards. It is only when such phenomena occur in an environment where they pose a threat to human life, property, infrastructure or the environment that they can be classified as hazards. Similarly in the case of technological developments, it is only when such developments pose a danger e.g. industrial accidents, infrastructure failures. In essence, a disaster is the result of a hazard's 
impact on society. So the effects of a disaster are determined by the extent of a community's vulnerability to the hazard.

Hazards in themselves do not constitute disasters. The magnitude of disaster, according to Niekerk, is usually described in terms of the adverse effects which a disaster has had on lives, property and infrastructure; environmental damage; and the costs attached to postdisaster recovery and rehabilitation. Simply out, therefore, disaster risk is the product of the combination of three elements vulnerability, coping capacity and hazard (ISDR, 2004). This interaction is illustrated in the following formula.

Disaster risk $(\mathrm{R})=$ Vulnerability $(\mathrm{V}) \mathrm{x} \operatorname{Hazard}(\mathrm{H})$

Capacity (C)

Hazards are increasingly dynamic and with highly varying potential impacts. A wide range of geographical, meteorological hydrological, environmental, technological, biological and socio-political hazards can threaten livelihoods and sustainable development.

Hazards can be classified into three broad categories:

- Natural hazards

- Technological hazards

- Environmental degradation.

It should be noted that all communities be it rural or urban is vulnerable to hazards. However, different regions will be more prone to certain types of hazards then others. Natural hazards are those triggered by climatic and geographical variability, which is at least partly beyond the control of human activity (Palm, 1990). Technological hazards represents dangers originating from technological or industrial accidents, dangerous procedures, infrastructure failures or certain human activities, which may cause the loss of life or injury, property damage, social and economic disruption or environmental degradation. Degradation of the environment is processes induced by human behaviour and activities (sometimes combined with natural hazards) that damage the natural 
resource base or adversely alter natural processes or ecosystems. Potential effects are varied and many contribute to an increase in vulnerability and the frequency and intensity of hazards.

\section{Threat, Vulnerability and Risk}

The term vulnerability has taken on a new and increased importance due to the greater scale of disasters. In general terms, it may be defined as the probability of a community exposed to a natural threat, given the degree of fragility of its elements (infrastructure, housing, productive activities, degree of organization, warning systems, political and institutional development), suffering human and material damages. The magnitude of such damage is, in turn related to the degree of vulnerability.

Vulnerability may be analyzed from different perspectives (physical, social, political, technological, ideological, cultural and education, environmental, institutional), although in one way or another all are actually related. It is a direct result of factors said to be anthropogenic that is, related to the interaction between man and nature. Risk arises as a product of the priori function linking threat and vulnerability, and is intrinsic and latent within society, although its level, degree of perception and means used to confront it, depend on the guidelines laid down by that society. All in all, vulnerability and risks are related to the political decisions a society has taken over time and therefore, depend on a country's or region's development. Vulnerability is, therefore, a precondition that reveals itself during a disaster, when not enough has been invested in prevention and mitigation, and an excessively high risk level has been accepted. This shows that when defining a preventive policy, before all else vulnerability must be reduced, since the forces of nature cannot themselves be eliminated. Nevertheless, it must be made clear that an analysis of vulnerability of structures is not enough, and the structure of vulnerability must also be understood: what or who is vulnerable and why?

It must be added that the most fragile and vulnerable population groups are the poor, and among them, women, children and ethnic 
minorities. The poor line in the areas at greater risk, use environmentally damaging farming techniques or work marginal land, have less access to information, basic services and pre and post disaster protection. This greater vulnerability of poor population groups is also related, where the democratic political system is limited or precarious to their scarce possibilities of participation in public politics. In many ways, poverty closes and exacerbates the vicious circle of disasters.

Hazard is a potentially damaging physical event, phenomenon or human activity, which may cause the loss of life or injury, property damage, social and economic disruption or environmental degradation. Empirical evidence indicates that hazards can include hidden (or unforeseen) conditions that may represent future threats and can have a number of different root causes. These include hydrometrological (e.g. flood), biological (disease epidemic such as HIV/AIDS) and/or induced by human processes (e.g. logging, September 11, 2001 event in New York, U.S.A.) and technological hazards (e.g. vehicular brake failures), etc.

Violent Conflict is defined as organized acts of social and political violence pitting one or more groups against one another and/or the state, or pitting states against each other. Violent conflict can be manifested in some form of armed conflict. While conflict is a normal and not necessarily negative part of social and economic transformation, violent conflict is always destructive. Violent conflict is distinguished from criminal violence (organized and otherwise) and household (domestic) violence in that it is typically massive in scale and organized with political or ideological ends. Violent conflict is exemplified by war and armed struggle between one or more groups (e.g. organized peasants, indigenous peoples, labour and/or political groups) resulting in mass violence.

Terrorism, a form of warfare, is a classical example of violent conflict. It is defined as the use of violence, often against people not directly involved in a conflict, by groups operating clandestinely, 
which generally claim to have high political or religious purposes, and believe that creating a climate of terror will assist in the attainment of their objectives.

Natural Hazards result from natural phenomena such as earthquakes, hurricanes, tidal waves, droughts, volcanic eruptions and landslides. They typically leave physical destruction, disability and death in their wake and disrupt economic activities and production. Natural hazards can also provoke severe pollution and other environmental damages. However, unlike violent conflicts, they are not typically characterized for producing severe effects on institutions, social capital and social cohesion. In fact, the populace tends to galvanize around natural disaster response and social solidarity is often reinforced. They are usually of short and intensive duration, and episodic or seasonal in character.

Technological Disasters are those originated by faulty design, construction or operation of man-made materials and systems. Examples range from structural collapse to explosion, conflagration, pollution, contamination and/or some combination thereof. Like natural hazards, technological disasters may be short in duration, but have long-term impacts such as in the case of a nuclear meltdown.

The Linkages between natural hazards and human-driven disasters and distressing environmental and humanitarian situations are increasingly present, particularly as the poor are compelled to exploit scarce environmental resources simply for survival. Deforestation, land degradation, and related food security are shaped by human resource use (e.g. urban squatting on marginalized hillsides), in turn sometimes creating conditions for flooding, landslides and drought.

\section{Triggers}

Disasters have a range of triggers. Natural hazards may be triggered by events such as earthquakes, tidal waves (Tsunamis), hurricanes, volcanic eruptions (lava, ash, rock), floods, drought, epidemics, forest fires, and erosion, or some combination thereof, and technological 
accidents by such human-made events as explosions, oil spills, and chemical mishaps. To ensure an integrated approach by all relevant role players in assessing hazards and determining the risk and vulnerability in our communities, there is need for risk and vulnerability analysis. The following steps should be followed in order to engage in risk and vulnerability analysis.

- Identify the nature, extent, and risk of hazards;

- Determine the existence and degree of vulnerabilities;

- Identify the capabilities and resources available;

- Determine the acceptable levels of risk, cost-benefit considerations;

- Set priorities relative to time, resource allocation effectiveness of results;

- Develop methods to protect people and key resources and reduce overall losses;

- Design effective and appropriate management systems to implement and control.

The strategies that can be used for the improvement of the application or risk and vulnerability analysis, according to Niekerk (2002) include the following:

1. Include analysis of natural hazard risk as part of on-going natural resource evaluation and development

2. Strategy formulation (in terms of integrated development planning).

3. Identify and formulate mitigation measures for development investment project.

4. Make information on natural hazard and community vulnerability more widely available more accessible to emergency response and development planning departments.

5. Train planning technicians and decision-makers in hazard assessments, vulnerability analysis, and disaster mitigation appreciation and techniques. 
6. Review risk perceptions of different economic groupings, (e.g. farmers, fishermen, small business community, labourers etc.).

7. Special emphasis on "lifeline systems" vulnerability analysis.

8. Energy sector vulnerability in relation to natural hazard.

9. Floor hazard assessment and early flood alert systems as part of integrated development (or agricultural) projects.

10. Include hazard assessment and vulnerability reduction measures as a part of provincial and local development plans.

11. Include landslide hazard and vulnerability assessments in metropolitan areas and on critical transportation routes.

12. Use of geographical information systems in national, provincial, and local government level analysis of natural hazards, resources, populations, critical facilities, infrastructure.

The vulnerable elements that should be considered in the development planning process include:

Human Settlements

Human population and associated housing and services critical facilities:

\section{Critical Facilities}

1. Essential services such as telecommunications, water, energy and sanitation;

2. Emergency medical services, fire and police station, and disaster organizations; and

3. Local, national and international transportation facilities and carriers.

\section{Economic Production Facilities}

Major source of livelihood of the population, such as industries, banking and commerce buildings, public markets, agro processing plants and areas of agricultural production, livestock, forestry, mines and fisheries production. 


\section{Public Assembly Sites}

Public assembly sites include buildings such as schools, churches, auditoriums, theatres, public markets and public and private office buildings.

\section{Cultural Patrimony}

This includes buildings of significant cultural and community value or use, and building of architectural importance.

5. Hyogo Declaration and Hyogo Framework for Action

Delegates to the World Conference on Disaster Reduction, gathered from 18 to 22 January 2005 in Kobe City of Japan's Hyogo Prefecture, which was affected by the Great Hanshin-Awaji Earthquake of 17 January 1995. The Delegates to the conference recognized that the international community has accumulated much experience with disaster risk reduction through the International Decade for Natural Disaster Reduction and the succeeding International Strategy for Disaster Reduction. In particular, by taking concrete measures in line with the Yokohama Strategy and Plan of Action for a Safer World, we have learned much, including about gaps and challenges since the 1994 Yokohama Conference. Nevertheless, there was a deep concern that communities continue to experience excessive losses of precious human lives and valuable property as well as serious injuries and major displacements due to various disasters worldwide.

While reaffirming the vital role of the United Nations system in disaster risk reduction, the delegates pledge their determination to reduce disaster losses of lives and other social, economic and environmental assets worldwide, mindful of the importance of international cooperation, solidarity and partnership, as well as good governance at all levels.

Thus, the following declarations were made: 
1. We will build upon relevant international commitments and frameworks, as well as internationally agreed development goals, including those contained in the Millennium Declaration, to strengthen global disaster reduction activities for the twenty-first century. Disasters have a tremendous detrimental impact on efforts at all levels to eradicate global poverty; the impact of disasters remains a significant challenge to sustainable development.

2. We recognize the intrinsic relationship between disaster reduction, sustainable development and poverty eradication, among others, and the importance of involving all stakeholders, including governments, regional and international organizations and financial institutions, civil society, including non-governmental organizations and volunteers, the private sector and the scientific community. We therefore welcome all the relevant events that took place and contributions made in the course of the Conference and its preparatory process.

3. We recognize as well that a culture of disaster prevention and resilience, and associated pre-disaster strategies, which are sound investments, must be fostered at all levels, ranging from the individual to the international levels. Human societies have to live with the risk of hazards posed by nature. However, we are far from powerless to prepare for and mitigate the impact of disasters. We can and must alleviate the suffering from hazards by reducing the vulnerability of societies. We can and must further build the resilience of nations and communities to disasters through people-centered early warning systems, risks assessments, education and other proactive, integrated, multi-hazard, and multi-sectoral approaches and activities in the context of the disaster reduction cycle, which consists of prevention, preparedness, and emergency response, as well as recovery and rehabilitation. Disaster risks, hazards, and their impacts pose a threat, but appropriate response to these can and should lead to actions to reduce risks and vulnerabilities in the future. 
4. We affirm that States have the primary responsibility to protect the people and property on their territory from hazards, and thus, it is vital to give high priority to disaster risk reduction in national policy, consistent with their capacities and the resources available to them. We concur that strengthening community level capacities to reduce disaster risk at the local level is especially needed, considering that appropriate disaster reduction measures at that level enable the communities and individuals to reduce significantly their vulnerability to hazards. Disasters remain a major threat to the survival, dignity, livelihood and security of peoples and communities, in particular the poor. Therefore there is an urgent need to enhance the capacity of disaster- prone developing countries in particular, the least developed countries and small island developing States, to reduce the impact of disasters, through strengthened national efforts and enhanced bilateral, regional and international cooperation, including through technical and financial assistance.

5. The Hyogo Framework for Action 2005-2015: Building the Resilience of Nations and Communities to Disasters with its expected outcome, strategic goals, and priorities for action, as well as implementation strategies and associated follow-up, as a guiding framework for the next decade on disaster reduction was therefore adopted.

\section{Disaster Risk Reduction for Development}

In recent years, there has been a major shift in how people seek to cope with disasters from natural hazards. While humanitarian response capacities are vital and needs continued attention, the focus on addressing risk underlines the recognition that human intervention designed to reduce the vulnerability of communities and their assets can reduce the impact of disasters.

Disaster risk reduction is a new paradigm in disaster management with a body of policies, strategies and practices geared toward curtailing vulnerabilities and disaster risks in a society through appropriate prevention, mitigation, preparedness and early warning 
programmes and facilities. It aims to motivate societies at risk to be more involved in the conscious management of risk and reduction of vulnerability in their communities. As a cross cutting issue, it demands substantial commitment from public authorities/civil society and a grater inter-sectoral and policy coordination at all levels. It also requires a full engagements of diverse tools used in the measurement of environmental vulnerability such as indicators and risk assessment. A system of comprehensive risk assessment and analysis, based upon detailed and accurate and successful disaster reduction strategy.

Risk is rooted in conditions of physical, social, economic, and environmental vulnerability. Such conditions require assessment and management on a continuing basis with the main aim of minimizing exposure to hazards. This is by strengthening relationships and by developing reliance on individual capabilities and institutional capacities that can withstand loss or damage, or those that will hasten discovery if loss or damage occurs (ISDR 2003).

Risk reduction measures are most successful when they directly involve the affected people in the disaster planning and decisionmaking processes at all levels. Strong participation in preventive actions and remedial programs is also important. Nevertheless, the primary level of disaster reduction lies at the community lev3el. Local leaders drawn from the various political, social and economic sectors of society have to assume primary responsibility for the economic sectors of society have to assume primary responsibility for the protection of their own community.

Promoting education and capacity building on how to manage and reduce risk from disasters is crucial. People's understanding of the issues and their ability to mobilize professional skills are essential components of any risk reduction strategy. Enabling communities by investing in human resources and building individual capabilities across the generations will have longer lasting value than any other specific investment in technological systems to reduce risks. 
Disaster reduction policies and measures need be implemented with a two-fold aim; to enable societies to be resilient to natural hazards while ensuring that development efforts do not increase vulnerability to these hazards. It is essential for communities to understand this philosophy for them to become more resilient to the effects of hazards and despite risks reduction was one important attribute amongst many other tenets, which is that o anticipating potential catastrophes based on knowledge of hazardous condition, and past devastations, which then prompts societies to unrest in protective measures.

Before present modern researches and development, there are indigenous protective methodologies, which dates back to the 14th and 15th century in Africa and Asia such as in the areas of terrace farming along the fragile steep slopes to protect erosion. In the Yoruba tribe of Nigeria, the indigenous farming makes it mandatory to allow farmland to fallow for some years to reduce environmental degradation and to allow for replenishment. Countries of Europe such as Netherlands with low lands usually around the sea level are known to have a tradition of erecting an extensive system of sea dykes to protect the people from floods and to reclaim marshlands.

In Nigeria, the indigenous farmers have mastered the act of forecasting arrival and or cycles of rain and possible floods and droughts through the sound of some birds and sprouting of some weeds and plants. The Japanese have age long tested traditional methods of predicting and reducing the impact of volcanic eruptions through early warnings and evacuations.

Over the years, different communities and professional groupings based on catastrophic experiences are known to have evolved and or adapted various measures to prevent and generally mitigate or reduce the impact of hazards in their various communities. These practices are called different names in different communities and at different time such as emergency assistances; civil defense disaster response, humanitarian assistance, civil protection, homeland security and 
disaster protection. Currently a more holistic approach with a focus on risk and vulnerability has midwife the concept of risk reduction or disaster risk management. While relief intervention is needful especially at the critical phase of disaster impact and thereafter, it is, however, criminal for policy decision maker to wait for disasters to occur before allocating resources to address the catastrophes.

\section{Institutional Framework for Disaster Management in Nigeria}

According to Otero and Marti (1995), some intrinsic elements of the nation, society, or economy affected have, in general, implications for the efforts needed to face the emergency, undertake reconstruction, and finally, surmount the consequences of the disaster. Relative size of the economy affected, the magnitude and depth of the event, and the economic and socio-political conditions of the country at the time are some of these elements. In response to the upsurge in disasters, the Federal Government of Nigeria through Decree No. 12 of 1999 established the National Emergency Management Agency (NEMA) as the apex public sector agency for emergency management. This legal instrument was fashioned after the USNEMA law, but its operation has been handicapped by several factors among which are inadequate funding and equipment, weak executive capacity and lack of decentralization.

The enabling legislation contains concepts like co-ordinate, liaise, monitor and collect, etc. which presupposes that NEMA is a cocoordinating agency. Yet, the Director-General of the agency in his welcome address to a recent conference on emergency management noted that the management of any emergency no matter how small is the agency's responsibility (Makarfi, 2004) It is instructive in this regard to note that current global climate models indicate that the sea level will rise irrespective of any interventions we make, which means that the coastal areas of Nigeria where virtually all the oil and gas installations are sited, including cities such as Lagos, Port-Harcourt and Warri, industrial plants and millions of poor people. For Nigeria, this situation is exacerbated by tropical storm surges, coastal erosion and flooding especially during the rainy season. 
Although Nigeria has signed up to the United Nations Framework Convention for Climate Change (UNFCCC), and is widely recognized to be vulnerable to climate change, much still needs to be done to develop local awareness, knowledge and expertise. Whereas, NEMA is structurally incapacitated, the situation is worse at the state and local levels. Although the 1999 NEMA Decree directs each state to have a fully equipped emergency management agency, this has not been realized. Furthermore, a National Disaster Response Plan was prepared about three years ago, it has not been put to use. It is however quite heartening that the Nigeriasat-1 (satellite) is now gathering data on environmental conditions and resources, we are concerned with the application of such data for participatory and sustainable environmental emergency management. The various actions and intentions of government in this sector are quite laudable. However, it is very critical that an appraisal of the framework, relationships, logistics and public awareness and willingness to participate in disaster prevention and management be carried out.

Although Nigeria has signed up to the United Nations Framework Convention for Climate Change (UNFCCC), and is widely recognized to be vulnerable to climate change, much still needs to be done to develop local awareness, knowledge and expertise. Whereas, NEMA is structurally incapacitated, the situation is worsening at the state and local levels. Although the 1999 NEMA Decree directs each state to have a fully equipped emergency management agency, this has not been realized. Furthermore, a National Disaster response Plan was prepared about three years ago, it has not been to use. It is however quite heartening that the Nigeriasat-1 (satellite) is now gathering data on environmental conditions and resources, we are concerned with the application of such data for participatory and sustainable environment emergency management.

\section{Disasters Occurrence in Nigeria}

Four main categories of disasters have occurred in Nigeria over the past ten years, and they have had significant human and environment consequences. These include: 


\section{Industrial/Technological Accidents}

Under this heading, some of the disasters that have occurred in Nigeria include

- On July 10 2000, a pipeline in Nigeria exploded killing about 250 villagers accompanied by wild fires burning out of control over about $20 \mathrm{~km}$ from the town of Jesse, Delta State.

- On 27 January 2002, at least 660 people were drowned and thousands were rendered homeless after a multiple bomb explosions at a Nigerian Military armoury in Lagos, triggered by an accidental fire. Mass panic ensured.

- The 2002 textile factory fire accident in Lagos killing hundreds of workers.

- Plane crash incidents, the most recent being the 10/22 Bellview airline flight 210 crash near Lagos in which 117 people died.

\section{Urban Violence, Civil Strife and Conflicts:}

Some of these are related to community land resource ownership; for instance,

- On 4 June 1999, ethnic clothes flamed up in Nigeria's southern oil industry hub of Warri, Delta State. Dozens of people were reported dead in six days of fighting.

- On 19 July 1999 at least 60 people died in clashes between Hausa and Yoruba tribes near Lagos.

- On 26 July 1999, troops were sent to Kano after at least 60 people were killed in renewed ethnic clashes in northern Nigeria.

- Several incidents of urban violence occurring frequently in major urban centres, claiming hundreds of lives and property.

\section{Property Rights and Unequal Sharing of Benefits from Natural Resources}

- On 1 January 1999, at least 19 people died in clashes in Nigeria's oil region after an ultimatum to oil firms to leave ethnic Ijaw areas. 
- On 3 June 1999, local youths set fires at four separate points on the Warri-Kaduna products pipeline near the village of Adeje, after police arrested suspected product thieves. The number of dead was undetermined.

\section{Rural and Urban Poverty which Lead People to Taking Deadly Risks to Get Money}

- On 18 October 1998, fire engulfed more than 2000 villagers who were scrambling for petrol near a ruptured pipeline in Jesse outside Warri. Nearly 1000 people were killed.

- On 14 March 1999, at least 50 villagers who were scooping up gasoline from a broken products pipeline at UmuichiechiUmungbede village in Abia State were burned to death after an explosion.

- There have been several incidences of pipeline vandalisation aimed at siphoning oil in different parts of the country especially Lagos, Ibadan and the Niger Delta leading to thousands of death.

Available literature on Nigeria shows the existence of spatial differences in the nature of disasters. While oil and gas pollution is largely a Niger Delta problem, drought and quella birds infestation occur in the Sudano-Sahelian states (e.g. Kano, Sokoto, Katsina, Borno and Yobe). However, soil erosion, rainstorn and flood disasters are prevalent in virtually all the states. (NEMA, 2002). The country has witnessed several disasters accompanied by numerous casualties including property damage. In 2001, the communal conflict in Akampa Local Government Area in Cross River State led to the displacement of about 3,000 people and 12 dead. The Tiv/HausaFulani clash in Nasarawa State culminated in the death of 50 persons and displacement of 50,000 people. Furthermore, during the same period the flood disasters in Aba, Kirfi (Bauchi State), Tal;ata Mafara (Zamfara State) led to the dislocation of about 13,000 people although no casualties were recorded (Orebiyi, 2002). 


\section{Disaster Management in Nigeria: The Challenges Ahead.}

There is need to create a disaster Management Information System (DMIS). According to Gupta (2001), preparing a template for disaster management including the following seven issues

a. Database: On various resources, skills, and services required for relief at short notice. It will have information on safety equipments and various other equipments, skills and other information required to deal with emergency.

b. Logistics: One of the most difficult problems to be handles is the organization of supply chain relief. There is the need, therefore to put all elements of logistics in place for tracking the supplies and distribution of relief materials.

c. Technological Needs: Whole range of technical questions regarding buildings, rescue and relief always emerge during emergency. The best practices have to be put in use.

d. Self Reliance: The lessons of community self-help need to be put together. A database of volunteers who can move at short notice need to be developed.

e. Communication infrastructure: This could pose a serious problem during emergency. It will require a network of harm radios, use of radio stations, setting up of help lines, etc. There is also the need to create information dissemination system and develop mechanism for capacity building.

f. Emergency Preparedness: There is need to organized drills to keep society prepared for dealing with emergencies. Those living in fragile areas, especially along major river channels need to regularly informed about the hazards of living in such areas.

g. Forecasting: Wherever possible, disasters which can be anticipated overtime or space need to be looked into.

It is generally accepted that the best disaster planning and management involves the following (Sorensen, 1988; Quarantelli, 1991): 
- Views disasters as different from accidents and minor emergencies;

- Views catastrophes as different from disasters;

- Focuses on multiple hazards and is generic rather than agent specific;

- Includes all four time phases of the planning process: mitigation, preparedness, response, and recovery;

- Aims at multiple rather than single hazard or risk reduction goals;

- Focuses ion general principles rather than specific details;

- Highlights a continuing process rather than an end product, such as the production of a written plan or a document for mitigation.

- Builds on research findings derived from systematic data in addition to personal experiences;

- Emphasizes the need for coordination both within and between organizations and segments of the community, rather than "command and control"; and

- Distinguishes between planning and managing, between the strategies and the tactics necessary.

\section{Conclusion}

When placed in the context of sustainable development, disaster management represents an important aspect of socio-economic and national security, therefore facilitating a continuous development process. Disaster reduction policies and measures need be implemented with a two-fold aim; to enable societies to be resilient to natural hazard while ensuring that development efforts do not increase vulnerability to these hazards. 


\section{References}

Applied Technology Council (ATC). (1985). Earthquake Damage Evaluation Data for California. ATC - 13 Report. Redwood City, CA and Washington, D.C

Blaikine, P. Cannon, T. Davis, I. and Wisner, B. (1994). At Risk: Natural Hazards, People's Vulnerability, and Disasters. London: Routledge.

CERD (2000). "EM-DAT: The OFDA/CRED International Disaster Database". http.//www.md.vcl.ac.be/cred/.

Clarke C. L and M. Munasinghe, (1995). "Economic Aspects of Disasters and Sustainable Development: An Introduction". In Clarke, C. L. and M. Munasinghe (eds) Disaster Prevention for Sustainable Development: Economic and Policy Issues. The International Decade for Natural Disaster Reduction (IDNDR) and The World Bank.

Colleta, N. J (2004). "Human-Driven Disasters: Violent Conflict, Terrorism and Technology". Inter-American Development Bank Sustainable Development Department: Technical Paper Series.

Comfort, L. K. (1990). "Turning Conflict into Cooperation: Organization Designs for Community Response in Disasters." International Journal of Mental Health 19(1), 89-108.

Comfort, L. K. (1991). "Designing an Interactive, Intelligent, Spatial Information System for International Disaster Assistance." International Journal of Mass Emergencies and Disasters 9(3), 339354.

Drabek, Thomas E. (1997). "Following Some Dreams: Recognizing Opportunities, Posting Interesting Questions, and Implementing Alternative Methods." International Journal of Mass Emergencies and Disaster 15(1), 21-46.

ECLAC-ADB. (2000)."La Reduccion de la Vulnerabilidad Frnte a los Desastres. LC/MEX/L. 428. Mexico". International Financial Corporation (IFC) 2000. The Central American Market for Insurance, Working Document. Washington, D.C

Farazmand, Ali. (2003). "Chaos and Transformation Theories: A Theoretical analysis with Implications for Organization Theory and Public Management." Public organization Review: A Global Journal 3, 339-372.

Federal Emergency Management Agency (2000). "Project Impact". http.www.fema.gov/impact 
Freeman, J (2001). "National Systems and Institutional Mechanisms for Comprehensive Disaster Risk Management Phase I". Background Study for the Regional Dialogue on Disasters. IDB.http://www.iadb.org

Garb, S., and E. Eng (1969). Disaster Handbook. New York: Springer.

Henderson, L. J. (2004). "Emergency and Disaster: Pervasive Risk and Public Bureaucracy in Developing Nations". Public Organization Review: A Global Journal 4:103-119.

International Strategy for Disaster Reduction (ISDR) (2002). Living with Risk: A Global Reviews of Disaster Reduction Initiatives. Preliminary Version. Geneva: ISDR Secretariat.

International Strategy for Disaster Reduction (ISDR) (2002)."Background Paper No.5 for WSSD." United Nations International Strategy for Disaster Reduction, No.1.

Jegillos, S. (1999). "Fundamentals of Disaster Risk Management: How are South East Abian Countries Addressing this?" In: Holloway, A. Risk, Sustainable Development and Disasters. Southern Perspective. Cape Town: Periperi Publications.

Keipi, K and Tyson, J. (2002). "Planning and Financial Protection to Survive Disasters". Inter-American Development Bank Sustainable Development Department. Technical Paper Series. www.iadb.org/sds/ENV/Publication.

Koehler, Gustav A., Guenther G. Kress, and Randi L. Miller. (2001). "What Disaster Response Management Can Learn from Chaos Theory." in Ali Farazmand (ed.), Handbook of Crisis and Emergency Management. New York: Marcel Dekker, pp. 617-626.

Kreima, A. and M. Munasinghe (1991). Managing Natural Disaster and the Environment. Washington, D. C.: World Bank.

Lenneal J. Henderson (2004). "Emergency and Disaster: Pervasive Risk and Public Bureaucracy in Developing Nations". Public Organization Review: A Global Journal_Vol. 4 pp 103-119

Lester, R. (2000). "Policy Issues in the Choice of Funding Instrument for Natural Disasters". Washington, D.C: Disaster Management Facility, World Bank.

Lohman, E.J.A. (1992). "Policies, Institution-Building and Legislation for Land-Use Management in Disaster-Prone Countries". United Nations Disaster Relief Organization News, pp. 8-11 
Mc Entire, David A. (2001). "Triggering Agents, Vulnerabilities and Disaster Reduction: Towards a Holistic Paradigm". Disaster Prevention and Management: An International Journal. Vol. 10(3); 189-196.

Moor, J. (2001). "Cities at Risk" Habitat Debate Vol. 7, No.4.

Niekerk D. (2002). "Disasters and Sustainable Development". African Center for Disaster Studies. Potchefstroom University, South Africa.

OFDA-CRED. 1999. EM-DAT: International Data Base. Universite Catholigue de Louvain, Brussels, Belgium http://www.md.ucl.ac.be/cred.

Ojo, E.E. (2003). "Disasters and Sustainable Development: Some Reflections and African Perspective". Paper prepared for Certificate Course in Disaster Studies. ACDS, Potchestroom University, South Africa.

Ojo, O. E. (2003). "Disaster Studies: Some Theoretical and Conceptual Reflections Module 1" Submitted to the African Centre for Disaster Studies, Potchefstroom University, South Africa.

Orebiyi, Abiodun (2002). "Nigerian Red Cross Society: 2001 Central Council Report". Unpublished Report by Headquarters of Nigerian Red Cross Society, Lagos.

Otero, R. C and R. Z. Marti (1995). "The Impacts of Natural Disasters on Developing Economies: Implications for the International Development and Disaster Community".

Paul K. F., Leslie A. M., J. Linnerooth-Bayer, Reinhard M., Georg P., Koko W. (2003). "Disaster Risk Management: National Systems for the Comprehensive Management of Disaster Risk and Financial Strategies for Natural Disaster Reconstruction”. Inter-American Development Bank, Washington D.C

Stallings, Robert A. (1997). "Methods of Disaster Research: Unique or Not?" International Journal of Mass Emergencies and Disaster 15(1), 719.

UNEP (1990). "Strategic Framework on Emergency Prevention, Preparedness, Assessment, Mitigation and Response".UNEP, Nairobi, Kenya

United Nations Disaster Management Training Programme (1992). An Overview of Disaster Management. (2nd Edition). USA: UNDP.

Wani, I. J. (2001) ."African Humanitarian Assistance and Disaster Relief Operations - A Case Study of Multilateral Cooperation". www.ndu.edu/inss/symposia/pacific 2001/wanipaper. 
Sustainable Disaster Risk Reduction in Nigeria: Lessons for developing Countries

Yitambe (2003). "From Everyday Hazards to Disasters: The Accumulation of Risk in Urban Areas". Environmental and Urbanization Vol. 15 No. 1 pp. 193-203.

Figure 1: Natural Hazard, Vulnerability and Risk

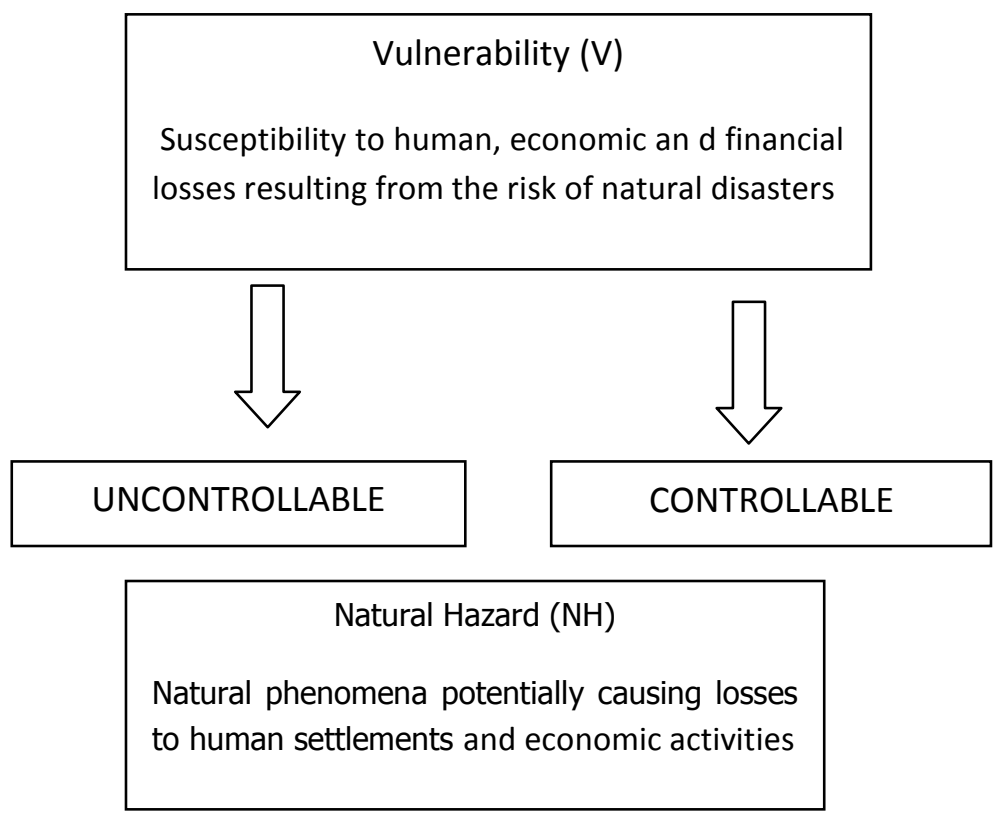


Table 1: Typology of Disaster Triggers

\begin{tabular}{|c|c|c|}
\hline \multirow[b]{2}{*}{ Natural Hazards } & \multicolumn{2}{|c|}{ HUMAN-DRIVEN DISASTERS } \\
\hline & Violent Conflict & Technological Hazards \\
\hline $\begin{array}{l}\text { Earthquakes } \\
\text { Floods/Riverbank erosion } \\
\text { Landslides } \\
\text { Cyclones/Typhoons/Hurricanes } \\
\text { Tsunami/Tidal Waves } \\
\text { Volcanic eruptions } \\
\text { Fire - forest, other } \\
\text { Unusually cold weather/winter } \\
\text { emergencies Drough }\end{array}$ & $\begin{array}{l}\text { Mass violent civil disturbances } \\
\text { International conflict } \\
\text { Civil war } \\
\text { Localized armed conflict } \\
\text { Terrorism }\end{array}$ & $\begin{array}{l}\text { Nuclear contamination } \\
\text { Industrial disasters } \\
\text { Poisoning of water courses - } \\
\text { chlorine, cyanide, mercury, lead, } \\
\text { etc. } \\
\text { Environmental pollution } \\
\text { Dam and structure failures } \\
\text { Oil spills }\end{array}$ \\
\hline
\end{tabular}

Source: Keipi and Tyson (2002)

PHENOMENA/EXAMPLES

\begin{tabular}{|c|c|}
\hline GEOLOGICAL HAZARDS & $\begin{array}{ll}\text { - } & \text { Earthquakes } \\
\text { - } & \text { Tsunamis (also called tidal waves) } \\
\text { - Volcanic activity and emissions } \\
\text { - } \quad \text { Mass earth movements e.g. landslides, rockslides, rock fall, } \\
\text { liquefaction, sub marine slides, } \\
\text { - Subsidence, surface collapse, geological fault activity. }\end{array}$ \\
\hline $\begin{array}{c}\text { HYDROMETEOROLOGICAL } \\
\text { HAZARDS }\end{array}$ & 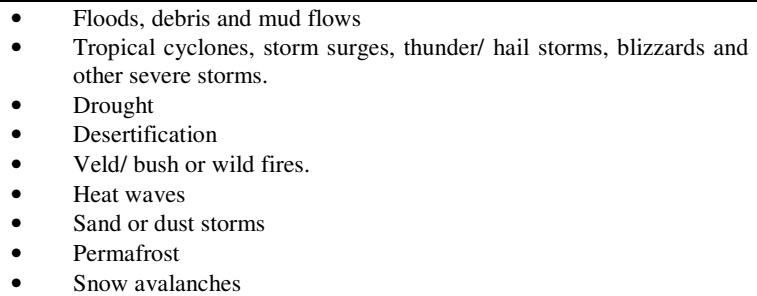 \\
\hline BIOLOGICAL HAZARDS & $\begin{array}{ll}- & \text { Outbreaks or epidemic disease } \\
\text { - } & \text { Plant or animal contagion } \\
\text { Extensive infestations }\end{array}$ \\
\hline TECHNOLOGICAL HAZARDS & $\begin{array}{ll}\text { - } & \text { Industrial pollution } \\
\text { - } & \text { Nuclear activities and radioactivity } \\
\text { - } & \text { Toxic wastes } \\
\text { - } & \text { Tran failures } \\
\text { - } & \text { Industrial accidents (explosion, fires, spills) } \\
\end{array}$ \\
\hline $\begin{array}{l}\text { ENVIRONMENTAL } \\
\text { DEGRADATION }\end{array}$ & $\begin{array}{ll}\text { - } & \text { Land Degradation } \\
\text { - } & \text { Deforestation } \\
\text { - } & \text { Desertification } \\
\text { - } & \text { Leld /bush /wildfires } \\
\text { - } & \text { Land, wiodiversity } \\
\text { - } & \text { Climate change } \\
\text { - } & \text { Sea level rise } \\
\end{array}$ \\
\hline
\end{tabular}


Table 2: Highlights and Spatial Distribution of Major Disasters in Nigeria

\begin{tabular}{|c|c|c|c|}
\hline $\mathrm{S} / \mathrm{NO}$ & State & Types of major disasters & Remark \\
\hline 1. & Abia & $\begin{array}{l}\text { Rainstorm: soil erosion \& market } \\
\text { fires }\end{array}$ & Soil erosion is a prevailing market fires frequent \\
\hline 2. & Adamawa & Armed bandity, flood, soil erosion & Soil erosion is a prevailing disasters \\
\hline 3. & Akwa Ibom & Flood, rainstorm and fire & Soil erosion is a prevailing disasters \\
\hline 4. & Anambra & $\begin{array}{l}\text { Rainstorm and armed banditry \& soil } \\
\text { erosion }\end{array}$ & Soil erosion is a prevailing disasters \\
\hline 5. & Bauchi & Fire and windstorm, religious crisis & Armed banditry is rampant \\
\hline 6. & Bayelsa & Flood \& coastal erosion, oil pollution & $\begin{array}{l}\text { Oil pollution \& youth restiveness are the } \\
\text { commonest problem }\end{array}$ \\
\hline 7. & Benue & $\begin{array}{l}\text { Communal clash \& bush fire, } \\
\text { flooding }\end{array}$ & $\begin{array}{l}\text { Communal clashes \& fire disasters are the } \\
\text { commonest crises }\end{array}$ \\
\hline 8. & Borno & Desert encroachment, fire and flood & Desertification is the major problem \\
\hline 9. & Cross River & Fire disaster \& oil pollution & Oil pollution if the major problem \\
\hline 10. & Delta & $\begin{array}{l}\text { Flood, rainstorm, oil pollution, youth } \\
\text { unrest }\end{array}$ & $\begin{array}{l}\text { Oil pollution if the major problem and youth } \\
\text { unrest }\end{array}$ \\
\hline 11. & Ebonyi & Soil erosion, bush fires & $\begin{array}{l}\text { Soil erosion and bush fire are the commonest } \\
\text { problem }\end{array}$ \\
\hline 12. & Edo & $\begin{array}{l}\text { Flood and rainstorm, oil pollution \& } \\
\text { youth restiveness }\end{array}$ & $\begin{array}{l}\text { Oil pollution \& youth restiveness are the } \\
\text { prevailing problems }\end{array}$ \\
\hline 13. & Enugu & Soil erosion, rainstorm \& flood & Rainstorm \& soil erosion are common \\
\hline 14. & Ekiti & Rainstorm, flood & Rainstorm \& soil erosion are common \\
\hline 15. & Gombe & Desertification & Desertification and rainstorm are common \\
\hline 16. & Imo & Rain and windstorm, soil erosion & Soil erosion is he major problem in the area \\
\hline 17. & Jigawa & Flood, fire, windstorm and flood & Desertification is the major problem \\
\hline 18. & Kaduna & $\begin{array}{l}\text { Fire, rainstorm, windstorm and } \\
\text { communal clash, flood }\end{array}$ & $\begin{array}{l}\text { Ethnic-religious clashes are the commonest } \\
\text { problems in the area }\end{array}$ \\
\hline
\end{tabular}




\begin{tabular}{|c|c|c|c|}
\hline 19. & Kano & $\begin{array}{l}\text { Flood, fire, windstorm and communal } \\
\text { clashes, plane crash }\end{array}$ & $\begin{array}{l}\text { Ethnic-religious clashes are the commonest } \\
\text { problems in the area }\end{array}$ \\
\hline 20. & Katsina & Fire, windstorm and flood & Desertification is the major problem \\
\hline 21. & Kebbi & Fire, windstorm and flood & Desertification is the major problem \\
\hline 22. & Kogi & Flood, fire and rainstorm & Rainstorm \& bush fires are the major problem \\
\hline 23. & Kwara & Flood, fire and rainstorm & Rainstorm \& bush fires are the major problem \\
\hline 24. & Lagos & $\begin{array}{l}\text { Bomb explosion, collapsed buildings, } \\
\text { erosion, flooding, plane crash }\end{array}$ & $\begin{array}{l}\text { Flooding is an annual even, armed banditry, } \\
\text { communal clashes are very frequent and } \\
\text { common place in the area }\end{array}$ \\
\hline 25. & Nasarawa & Communal clashes \& bush fires & Ethnic clashes is the major problem in the area \\
\hline 26. & Niger & Rainstorm, flooding & Flooding is common place in the area \\
\hline 27. & Ogun & Flooding, ethnic clashes, plane crash & Flooding is common place in the area \\
\hline 28. & Ondo & $\begin{array}{l}\text { Rainstorm, erosion \& communal } \\
\text { clashes }\end{array}$ & Flooding is common place in the area \\
\hline 29. & Osun & Rainstorm, communal clashes & Communal clashes are all too frequent \\
\hline 30. & Oyo & Flooding, rainstorm, erosion & Rainstorm \& flooding \\
\hline 31. & Plateau & Communal clash, bush fire, erosion & Communal clashes \& rainstorm \\
\hline 32. & Rivers & $\begin{array}{l}\text { Erosion, communal clash \& oil } \\
\text { pollution, flooding \& plane crash }\end{array}$ & $\begin{array}{l}\text { Youth restiveness and oil pollution are the main } \\
\text { crises and are all too frequent }\end{array}$ \\
\hline 33. & Sokoto & $\begin{array}{l}\text { Flood, quella birds, fire and flood and } \\
\text { windstorm }\end{array}$ & Windstorm, drought \\
\hline 34. & Taraba & $\begin{array}{l}\text { Ethno-communal clashes and bush } \\
\text { fires }\end{array}$ & Communal clashes are very frequent \\
\hline 35. & Yobe & Fire, drought, fire and flood & Drought is common \\
\hline 36. & Zamfara & Flooding, religious crises & Occasional flooding is not uncommon \\
\hline 37. & FCT & Windstorm, fire, flooding & Market fires are frequent \\
\hline
\end{tabular}

Source: After Response May-June, 2002, p. 30. 